Revue de l'Institut des langues et cultures

d'Europe, Amérique, Afrique, Asie et Australie

$31 \mid 2018$

Récits fictionnels et non fictionnels liés à des communautés professionnelles et à des groupes spécialisés

\title{
FASP, the FASPian Paradox and Specialised Encyclopaedias: Highlighting FASP Relevance in Learning/Teaching Specialised Languages
}

La FASP, le paradoxe FASPien et les encyclopédies spécialisées : la pertinence de

la FASP pour l'apprentissage des langues de spécialité

\section{Michel Van der Yeught}

\section{OpenEdition}

\section{Journals}

\section{Electronic version}

URL: http://journals.openedition.org/ilcea/4684

DOI: $10.4000 /$ ilcea.4684

ISSN: 2101-0609

\section{Publisher}

UGA Éditions/Université Grenoble Alpes

Printed version

ISBN: 978-2-37747-043-3

ISSN: 1639-6073

\section{Electronic reference}

Michel Van der Yeught, «FASP, the FASPian Paradox and Specialised Encyclopaedias: Highlighting FASP Relevance in Learning/Teaching Specialised Languages », ILCEA [Online], 31 | 2018, Online since 06 March 2018, connection on 22 April 2019. URL : http://journals.openedition.org/ilcea/4684 ; DOI : 10.4000/ilcea.4684

This text was automatically generated on 22 April 2019

(c) ILCEA 


\title{
FASP, the FASPian Paradox and Specialised Encyclopaedias: Highlighting FASP Relevance in Learning/Teaching Specialised Languages
}

\author{
La FASP, le paradoxe FASPien et les encyclopédies spécialisées : la pertinence de \\ la FASP pour l'apprentissage des langues de spécialité
}

\section{Michel Van der Yeught}

1 In 1999, Petit paved the way for the study of a new genre of modern thriller which he named fiction à substrat professionnel, quickly adopted as "FASP" in the ESP community. His approach was refined by further insights in 2004 (Petit \& Isani) and FASP studies are now prospering, notably on the French ESP scene. Petit's interest in FASP was justified by the pedagogical value of these specialised fictional narratives which, he suggested, opened alternative ways of access to specialised languages. Yet, the proposal gives rise to what may be called the "FASPian paradox" since Petit also recognises that FASP is not specialised discourse in the usual sense (1999: 79), potentially undermining the relevance of FASP in the learning of specialised languages.

2 This paper aims to address the FASPian paradox with a view to confirming the intuitive appreciation of FASP as an effective way of accessing specialised languages. First, while Petit insists on the connections of FASP authors with specialised communities and on the realism of FASP description, situations and professional substratum (1999: 63-65, 65-73), this paper resorts instead to the notion of "specialised encyclopaedia" and explains how it diverges from Petit's propositions. Second, it shows how FASP plots illustrate the centrality of encyclopaedic interpretation in FASP, especially in its "consult-the-expert scenes". It concludes by suggesting that the usual pedagogical applications that 
distinguish between FASP's content and language benefits should be recombined under the embracing notion of specialised encyclopaedias.

\section{Addressing the FASPian paradox}

\subsection{Moving beyond Petit's argumentation paradigm}

Numerous academics who study and teach specialised languages and practitioners of English for Specific Purposes (ESP) intuitively recognise the value of works of fiction for pedagogical purposes (Hirvela, 2013: 89). So much so that some university professors and authors in economics have written their own fiction to popularise classical theories among their students and wider audiences, which Resche calls "didactic economic fiction" (2004; also see Isani, 2004). Yet, the identification of FASP as an alternative way of access to specialised languages by Petit in 1999 leads to what I call the "FASPian paradox" since Petit also acknowledges that: (1) FASP is not a "primary discourse of specialised milieus"; and that (2) it belongs in "another paradigmatic group of discourse, that of literature" (2004: 9; see also 1999: 79). While I think that the paradox does not diminish the merits of FASP, I claim that it should be demonstrably solved to establish FASP as a fully legitimate instrument in ESP didactics.

4 In addressing the FASPian paradox, I do not intend to dwell on Petit's arguments in favour of FASP. Basically, they can be summarised as follows: FASP provides a realistic representation of professional milieus (2004: 10, 15); most FASP authors are professionals themselves (1999: 63-65); FASP is a product of professional cultures (2004: 22). I do not claim that these arguments are wrong or unconvincing, but that they may have some weaknesses or limitations. The first one is that the "author-as-professional" argument resorts to extra-textual biographical elements which may fit the case or not. For example, Ian Pears, when interviewed by Isani, admits that "There is no professional substrata in me except for my ability to find out about things I need to know about" (2004: 181). The same may be said about FASP being the products of professional cultures: that may or may not be the case depending on authors and books.

The value of FASP as a "realistic representation of professional milieus" also hovers on an argumentation minefield given the millennium-old debate about the effectiveness of fictional mimesis in conveying authentic reality: sometimes it does convincingly represent the real world, sometimes it does not. Petit rightly points out the scrupulous use of technical details in many FASP descriptions by authors such as Michael Crichton, Frederick Forsyth and Tom Clancy (1999: 69; see also Isani, 2004: 184-185); but, on the other hand, Chapon in her PhD dissertation shows how apparently true-to-life details in American law are wrongfully introduced into legal FASP television series because they fit the audience's preconceptions of legal reality (2015: 197-244; see also Charpy, 2010: 55-57). Petit himself has sensed that the "representation-reality" combination is both a convincing argument and a trap. He admits: "[...] il ne peut être qu'assez difficile de se dégager d'une problématique de la représentation [...]" ("it can be quite difficult to move beyond a problematic of representation") (2004: 22).

6 In this paper, my objective is precisely to move beyond Petit's representation paradigm, not because I take issue with it, but because I feel it needs to be strengthened from within the textual substance of FASP instead of resorting to extra-textual justifications. 


\subsection{FASP, from specialised discourse to specialised encyclopaedias}

7 To clarify the issue, the first step I need to take is to detail my answer to the question: is FASP specialised discourse? In a paper published in 2016, I agreed with Petit's negative answer, but from a slightly different viewpoint. I had observed that the primary function of FASP discourse is not to serve the purposes of specialised domains as specialised languages do. Law students do not read John Grisham to become lawyers and doctors do not read Robin Cook to improve their diagnoses: FASP serves narrative fiction and its readers' interest, not specialised domains (2016: 60).

Yet, it is undeniable that the professional substratum borne by FASP and aptly identified by Petit contains genuine specialised elements. My aim is to account for them without resorting to the notion of representation. My suggestion is that the very fabric of FASP texts, i.e. the plot, characters, narrative dynamics, environment, details and issues are convincingly put together in the form of novels because they constitute a network of mutually sustaining informative elements that convey an impression of specialised authenticity to readers. I am not saying that they "represent" specialised reality, but rather that they provide a discourse whose components lead the readers towards a form of interpretation that accurately evokes specialised domains.

Whether FASP authors are professionals from the domains they fictionalise or have researchers collect relevant data for them-the biographical aspect of the question is a moot point now-, some highly sophisticated form of expert knowledge is indeed mobilised in FASP works and artfully knitted together so as to satisfy the satisfactions of even the most demanding insiders. It seamlessly connects lexis, actions, places, historical events, technical details, behaviours, mindsets, problems and plot so that the multitude of connections coheres into specialised authenticity. It enables FASP writers to produce their best-sellers and insiders to appreciate them because they too can make sense of their cryptic specialised discursive nettings.

Such knowledge, described by Bhatia as "specific disciplinary culture", "prior knowledge of disciplinary or institutional conventions", "existing knowledge" or "pre-knowledge" (2004: 186-188), is both linguistic and extralinguistic because it offers correct interpretations by relating discourse to context. It is also unpredictable and potentially infinite since discourse-context situations, whether fictional or real, are also countless. I have suggested elsewhere (2016: 56-57) that the competence to make successful interpretive use of such relations is "encyclopaedic" in nature as it may draw from an infinite amount of knowledge.

11 In these cases, encyclopaedic knowledge does not refer to a fixed set of knowledge components as may be found in traditional encyclopaedias such as the Encyclopredia Britannica, nor even in a culture, but to the infinite potentialities of interpretive processes that can relate any element to any other in any imaginable order. In that sense, this notion of "encyclopaedia" is borrowed from Eco who defines it as follows:

In the interpretive process, encyclopaedic knowledge operates as a set of instructions that properly insert textual elements in their relevant contexts and achieve the correct disambiguation of terms. (1986: 68)

12 Eco uses the notion of encyclopaedia in a general philosophical sense, but a French linguistics and literature professor, Jean-Jacques Lecercle, has elaborated on Eco's notion to make it fit literary criticism: 
[Encyclopaedias] provide contextual meaning and deal with pragmatic interpretation. (1990: 140)

[Encyclopaedias] are linked to sets of contexts, that is, to cultures, and to sets of beliefs and knowledge held by speech communities or social (religious, ethnic, professional...) subparts of them. (1999: 202-204, 211)

Following Eco and Lecercle, I propose that the pre-knowledge required to interpret-and in the case of FASP, to produce-coded specialised discourse is similarly encyclopaedic and that the languages of specialised domains and communities are decipherable thanks to specialised encyclopaedias that facilitate interpretations (Van der Yeught, 2016: 57). In that line of thought, I suggest that FASP discourse is essentially "fictionalised encyclopaedic knowledge" (ibid.: 61). This property appears clearly in the very substance of FASP plots.

\section{FASP's interpretation-oriented dramatic functions and plots}

\subsection{Domain-specific dramatic function and encyclopaedic knowledge}

14 When presenting FASP narratives, Petit recalls the usual dramatic functions of thriller plots ("extra-ordinary" adventures, danger, murder, scams, crisis, enemies, villains...) (1999: 66-67). Still, he insists that the professional substratum operates as the major driving force in FASP plots (1999: 68). For example, in a murder case, the role of the professional protagonist is not to find and arrest the murderer, but "to solve a medical enigma" posed by the case. We understand that FASP novels combine two types of dramatic functions: "general ones" and "domain-specific ones".

As discursive mechanisms triggering narrative tension, general dramatic functions are largely universal; they have featured in history, tales, fiction, myths and theatre plays throughout the centuries. For example, Petit's sample is strikingly akin to the "functions of dramatis personae" identified by the Russian folktale analyst, Vladimir Propp, in his Morphology of the Folktale. The folktale hero faces deception, harm, murder, misfortune, lack (of a bride, money, sword, horse...). His mission is to solve tensions by punishing villains, restoring justice, finding money, often with the help of a "donor" or "provider" who offers a "magical agent" such as a ring or a password (2015 [1928]: 24-35, 36-37).

On the other hand, domain-specific dramatic functions typify the FASP genre as they provide the plot with a specialised context and logic. Within a given professional environment, the protagonist's mission is to resolve an enigma by resorting to his specialised expertise. Petit states that the hero's merits include personal qualities such as determination and resilience in the face of adversity (ibid.: 66), but the supreme merit here is "specific professional competence" (ibid.). When the enigma tests their competence to its limits, protagonists may resort to the advice of senior experts. These passages are described by Petit as "consult-the-expert scenes" (ibid.: 68-69).

of course, beyond FASP, consult-the-expert scenes are universal topoi as they fall within the category of the "hero's visit to a wiseman" which is a common storytelling theme. Indeed, many of the authorities consulted in FASP storytelling call for descriptions evoking solemn and authoritative Merlin-the-Magician characters in academic or medical guise. They are directly reminiscent of the "helpers", "donors" and "providers" in 
Propp's Russian folktales, except that their "magical agent" is not a ring or a password; the magic here is superior encyclopaedic knowledge and determining power of interpretation in their domains of excellence. This shift from traditional action-based plots to interpretation-based plots is precisely what distinguishes FASP as a new and original genre. Thus, in Robin Cook's Chromosome 6, the hero's former pathology professor consults a colleague who recommends seeing a veterinary pathologist (Cook, 1997: 333). This proves to be a decisive move ("Having the slide reviewed by a veterinary pathologist was something he'd not thought of [...]", ponders the hero) since the mutilated corpse's liver is found to come from an animal and not from a human being, a discovery which helps to disentangle the plot's enigma.

\subsection{Specialised encyclopaedias as solutions to the FASPian paradox}

Consult-the-expert scenes play a crucial role in many FASP novels because they are showcases displaying the interpretive power of encyclopaedic knowledge. They provide plot dynamics, add to the novel's thrill and contribute to solving the FASPian paradox. FASP may not be specialised discourse stricto sensu, but its productions are based on the authors' masterly grasp of specialised encyclopaedic knowledge which is the same as that of domain experts. The usefulness of the notion is that it helps to bypass the representation paradigm. A specialised encyclopaedia may well contribute to the production of a representation or mimesis of professional reality; yet, the main point here is that it is a form of knowledge shared by insiders that enables them to understand insider discourse. It is this commonality-it stretches from authors to readers via the novel-which makes FASP invaluable as an alternative way of access to specialised languages. By resorting to FASP in pedagogical settings, learners may access the specialist interpretive competence offered by the mobilised encyclopaedias and therefore specialised varieties of languages.

Encyclopaedic knowledge is not a synonym of faultless authenticity as Chapon, cited above, has shown. Nevertheless, even though certain aspects of FASP may be unauthentic, a faulty encyclopaedia, i.e. gross and widespread blunders leading to serious misinterpretations in specialised discourse-context messages, would certainly sink FASP as a literary and business proposition (Isani, 2006b: 97-99). The quality of recognised FASP novels, let alone of world-class best-sellers, lies in the cohesive granularity of their encyclopaedic interconnections and this merit has high pedagogical relevance.

\subsection{FASP, specialised encyclopaedias and pedagogical applications}

Since the origin of FASP studies, numerous pedagogical approaches have been proposed to make use of FASP to access specialised varieties of English (Van der Yeught, 2004; Trouillon, 2005: 59-62; Isani, 2006a, 2006b, 2009). However, most of them approach FASP contributions by examining benefits deriving from its content distinctly from benefits resulting from its language and discourse (Van der Yeught, 2004: 37-39; Isani, 2006b: 97-105). The suggestion put forward in this paper is that both types of benefits should be combined as interrelated components of specialised encyclopaedias. The notion always connects language to context and requires interpretive competence. These are the skills that produce insiders and, if learners are to become articulate insiders too, this 
perception of FASP calls for pedagogical applications that can stimulate encyclopaedic interpretation in specialised domains.

This paper highlights the value of FASP for pedagogical purposes as offering an alternative way of access to specialised languages by attempting to solve the FASPian paradox. However, it does not resort to the same series of arguments used by the founder of FASP studies, Michel Petit. The merit of FASP as an accurate, albeit fictional, representation of professional reality is downplayed in favour of another type of argument based on the fabric of the text itself. FASP is analysed as a product of specialised encyclopaedic knowledge, a notion derived from "encyclopaedia" as construed by Eco and Leclerc. The interesting aspect of the encyclopaedic approach is that it bypasses the representation paradigm by underscoring the fact that this type of knowledge is shared by all "insiders": the writer, the novel's protagonist and the readers who are either mature or would-be insiders. Thus, learners, as would-be insiders, can have access to specialised encyclopaedic knowledge through FASP, even though FASP is not specialised discourse stricto sensu. One key element in the approach is the "consultthe-expert scene" which illustrates the role played by encyclopaedic interpretation as a dramatic function of the plot. This effort to confirm the pedagogical relevance of FASP may open up new prospects too. It suggests that the definition of "authentic documents" in the study of specialised languages be kept open and flexible so as not to exclude a priori potentially interesting entrants. The latter's value has to be examined and discussed thoroughly before being judged on its merits. Thus, Alan Hirvela (2013: 89) calls for a "Literature for Specific Purposes framework", which may herald other potential challengers in opening new alternative routes to specialised languages.

\section{BIBLIOGRAPHY}

Bhatia Vijay K. (2004), Worlds of Written Discourse, London: Continuum.

CHAPON Sandrine (2015), Fiction à substrat professionnel télévisuel comme voie d'accès à l'enseignement/ apprentissage de l'anglais juridique (Unpublished $\mathrm{PhD}$ dissertation), Université Grenoble Alpes, Grenoble.

CHARPY Jean-Pierre (2010), "FASP médicale et substrat professionnel : Le miroir éclaté”, ASp (57), 49-65.

CоoK Robin (1997), Chromosome 6, London: Pan Books.

ECO Umberto (1986), Semiotics and the Philosophy of Language, Bloomington: Indiana University Press/Midland Book.

HIRVELA Alan (2013), “ESP and reading”, B. Paltridge \& S. Starfield (eds), The Handbook of English for Specific Purposes, Boston: Wiley-Blackwell, 77-94.

ISANI Shaeda (2004), "Interview with Ian Pears”, M. Petit \& S. Isani (eds), Aspects de la fiction à substrat professionnel, Bordeaux: Université Bordeaux Segalen, Travaux 20.25, 179-186. 
ISANI Shaeda (2004), “The FASP and the Genres within the Genres”, M. Petit \& S. Isani (eds), Aspects de la fiction à substrat professionnel, Bordeaux: Université Bordeaux Segalen, Travaux 20.25, 121-132.

ISANI Shaeda (2006a), "Revisiting cinematic FASP and English for Legal Purposes in a Self-learning Environment", Les Cahiers de l'APLIUT, 25(1), 27-38.

ISANI Shaeda (2006b), "Langue, lecture et littérature populaire : FASP et didactique des langues de spécialité”, Les Cahiers de l'APLIUT, 25(3), 92-106.

ISANI Shaeda (2009), "Specialised fictional narrative and lay readership: Bridging the accessibility gap", $A S p(56), 45-65$.

LECERCLE Jean-Jacques (1990), The Violence of Language, London: Routledge.

LECERCLE Jean-Jacques (1999), Interpretation as Pragmatics, Basingstoke, UK: Macmillan/Palgrave.

PETIT Michel (1999), "La fiction à substrat professionnel : une autre voie d'accès à l'anglais de spécialité", ASp (23-26), 57-81.

PETIT Michel (2004), “Quelques réflexions sur la fiction à substrat professionnel : du général au particulier”, M. Petit \& S. Isani (eds), Aspects de la fiction à substrat professionnel, Bordeaux:

Université Bordeaux Segalen, Travaux 20.25, 3-23.

PETIT Michel \& ISANI Shaeda (eds) (2004), Aspects de la fiction à substrat professionnel, Bordeaux: Université Bordeaux Segalen, Travaux 20.25.

PROPP Vladimir (2015), Morphology of the Folktale [1928], Mansfield Center, CT: Martino Publishing. RESCHE Catherine (2004), "La théorie économique au détour de la fiction : le roman didactique", M. Petit \& S. Isani (eds), Aspects de la fiction à substrat professionnel, Bordeaux: Université Bordeaux Segalen, Travaux 20.25, 135-151.

TROUILLON Jean-Louis (2005), "Entre texte et contexte : la fiction historique et la fiction à substrat professionnel”, ASp (47-48), 51-66.

VAN DER YEUGHT Michel (2004), “Le substrat professionnel dans Wall Street, le film d'oliver Stone", ASp (45-46), 21-42.

VAN DER YEUGHT Michel (2016), “A proposal to establish epistemological foundations for the study of specialised languages", ASp (69), 41-63.

\section{ABSTRACTS}

FASP (fiction à substrat professionnel, profession-based fiction) studies have enjoyed growing academic interest since Petit identified FASP as a new genre of specialised thriller (1999). Yet, what may be called the "FASPian paradox"-the proposition that FASP opens access to specialised language while it is not itself specialised discourse-has not been given sufficient attention although it undermines FASP's pedagogical relevance. This paper proposes to resolve the paradox by using the notion of "specialised encyclopaedia" derived from Eco (1986) and Lecercle $(1990,1999)$ in order to move beyond the representation paradigm generally used to defend the validity of FASP as a teaching instrument.

La FASP (fiction à substrat professionnel) bénéfice d'un intérêt grandissant de la part des chercheurs depuis que Petit l'a identifiée comme un nouveau genre de thriller spécialisé (1999). Néanmoins, ce que l'on pourrait appeler le «paradoxe FASPien»-proposition que la FASP 
ouvre un accès aux langues de spécialité alors qu'elle ne constitue pas elle-même un discours spécialisé - a été négligé bien qu'il amoindrisse la pertinence pédagogique de la FASP. Cet article s'applique à résoudre le paradoxe en ayant recours à la notion d'« encyclopédie spécialisée ", dérivée d'Eco (1986) et de Lecercle $(1990,1999)$ afin de dépasser le paradigme de la représentation généralement utilisé pour défendre la valeur de la FASP comme outil d'enseignement.

INDEX

Mots-clés: FASP, encyclopédie spécialisée, anglais de spécialité, variétés spécialisées de l'anglais Keywords: profession-based fiction, specialised encyclopaedia, English for specific purposes, specialised varieties of English

\section{AUTHOR}

\section{MICHEL VAN DER YEUGHT}

Aix Marseille Univ., LERMA, ED 354, Aix-en-Provence, France 